\title{
DAIRY WASTEWATER-A CASE STUDY
}

\author{
Swati A.Patil ${ }^{1}$, Vaishali V. Ahire ${ }^{2}$, M.H.Hussain ${ }^{3}$ \\ ${ }^{I}$ Department of civil Engg, University of Pune, SITRC, Nashik, Maharashtra \\ ${ }^{2}$ Department of mechanical Engg, University of Pune, SITRC, Nashik, Maharashtra \\ ${ }^{3}$ North Maharashtra university, SSBTCOET, Jalgaon, Maharashtra
}

\begin{abstract}
Environmental Engineering \& Pollution control are the growing concerns of today. Rising population technological, economical and industrial revolution and changing life style has lead to various types of environmental problems, water pollution, land pollution, Air pollution, nuclear pollution, sound pollution including spiritual pollution are the aspects of pollution today. Out of which, water pollution is most concerned with civil engineering. Water treatment, supply and waste water treatment of domestics and industrial sources is very important aspect of civil engineering. Present work deals with the industrial waste water treatment. In may also Dairy industry uses $4 L$ of water per L of milk, which cones out as a waste water, In fact, in a survey made by Environmental Protection Agency of U SA in 1950, the 2nd major cause of water pollution was dairy effluent (I) Dairy waste water is a diluted milk (1) It contains BOD, COD, total solids dissolved solids and sometimes PH and oil-grease as highly biodegradable and COD/BOD is less than 1.5
\end{abstract}

Keywords: -dairy waste water, treatment, characteristics, housekeeping

\section{INTRODUCTION}

Due to highly biodegradable nature of dairy wastewater its treatment requires urgent attention but as such treatment is not a big issue. Biological treatment technologies can readily treat the dairy wastewater. The final effluent can be readily used for irrigation and sludge itself becomes a good fertilizer.

If waste is disposed in water bodies or ground BOD becomes the major concern. It may lead to anaerobic conditions and related problems. The BOD is in a range of 1000 to $2000 \mathrm{mg} / \mathrm{L}$ (1) obviously, Biological threatening is required for it. The Biological treatment may be Activated sludge process, Trickling filter, aerated lagoon or oxidation pond. However anaerobic process is also found to be successful. Dairy waste water is an area, already quite exposed.

The present work is for an industry "Vikas Dairy". Also called as Jalgaon Jihla Dudh Utpadak Sangh Maryadit, Jalgaon". It is a Co-operative sector. The work includes following things.

1) Study of various process of industry.

2) Characterization of composite waste water.

3) Characterization of treated effluent and hence performance appraisal of treatment plant.

4) Study of treatment plant.

5) Study of industry's housekeeping.

We have collected composite samples from the industry , 5 times in peak durations, suggested by the industry person we analyzed them for BOD, COD, TS, pH, DS, VS, FS, alkalinity, acidity, DO etc. we found that the treatment given by the industry is excellent and housekeeping is also good. The treated effluent is used for irrigation purpose. As a scope for future work, we suggest for detailed analysis at other parameters, reuse scope and advanced treatment studies.

\section{OBJECTIVES OF PRESENT WORK}

1. Thorough Examination of Process of the Industry:

1. To identify the sources of wastewater generation,

2. To identify the scope wastewater minimization by process alteration.

2. Characterization of Wastewater: Dairy wastewater does not require segregated treatment. All analysis and treatment is done for composite wastewater. Garb samples are collected from balancing tank of the wastewater treatment facility and are analyzed for various parameters. This is done so as

1. To decide the type of treatment required by the wastewater.

2. To estimate the pollution effects of wastewater.

3. To compare the same with standards given in IS codes.

3. Study Existing Treatment Facility: The existing treatment facility is studied in detail with an objective to

1. To examine the suitability of treatment scheme adopted according to the characteristics of waste water.

2. To examine the adequacy of size of treatment units as compared to the quantity of waste water.

3. To compare the treatment scheme with the IS recommended schemes.

4. Effluent Characterization: The effluent grab samples are collected at the same time while collecting the raw wastewater samples and are characterized for various 
parameters. This is done so as:

1. To determine the efficiency of treatment facility

2. To compare the effluent characteristics with IS permissible limits.

3. To decide the suitable method of disposal of final effluent

4. To examine the scope of reuse of final effluent.

5. Housekeeping Observations: Housekeeping is growing concern now days. Housekeeping ensures good quality of production, cost minimization, waste minimization, and consequently environmental protection and saving on pollution control. Each and every process of the industry has been examined carefully from this aspect. The surroundings and campus are also observed with this view.

Dairy wastewater is an area that has been explored quite adequately by various researchers. Data base is available in the IS codes also. The present work is done with an objective to examine the industry under study, the standards and to further enrich the research database.

6. Design Verification of Treatment Units: The industry under study has an intake of around $175000 \mathrm{~L}$ of milk per day. Considering $4 \mathrm{~L}$ of water required per L of milk, quantity of waste water becomes $=4 \times 175000=700000$ L/day. For this quantity of flow, the various units of treatment plant are designed. Their sizes are calculated and are compared with the existing sizes. Thus the design of existing treatment plant is verified.

\subsection{Pasteurization}

Pasteurization is the process of heating liquid for the purpose of destroying viruses and harmful organism. It is different from sterilization because pasteurization only aims to reduce the number of bacteria so they are unlikely to cause disease. Sterilization is not common in food processing because it can affect the flavor.

Especially in the lean season and the preparation of cheese in India are on the increase. The various processes that are generally carried out on the milk in dairy industry are given as under:

Milk cans are unloaded at the receiving station and emptied into a receiving station and emptied tank after testing for physical fitness for their freshness. Cans which are turned sour are segregated. The milk from each lot is weighed and conveyed to the pasteurization and other units. Pasteurization is accomplished the heating either to $61.5{ }^{\circ} \mathrm{c}$ for $30 \mathrm{~min}$ or $71^{0} \mathrm{c}$ for 15 second. Milk is then bottled for distribution. It is the basic process carried out on all sorts of milks collected in the dairy and is done invariably before supplying milk directly or using it for any product making. Adjustment of temp is allowed to settle. The whey is then run off. The curd is then subjected to various processes depending on the type of cheese sting made.

\section{Pretreatments}

- Equalization

- Neutralization

- Separation / Clarification

\section{Secondary Treatments}

- Biological Methods

- Activated sludge process

- Aerobic process

- Oxidation ditch / trickling filters

- Rotating biological discs

- Anaerobic digestion

\section{TREATMENT OF DAIRY WASTE WATER}

The average volume of waste water in dairies is currently 1 to $3 \mathrm{~L} / \mathrm{kg}$ milk. This results in considerable waste water disposal costs. A schematic representation of treatment of dairy wastewater is given in fig .1

The present work is done for the waste water characterisation and performance appraisal of effluent treatment plant of a dairy named as - "Jalgaon Jilha Dudh Utpadak Sangh Morydit Jalgaon". All the product of this dairy are with a prefix of vikas so the diary is also known as vikas dairy. The industry is a co-operative sector and presently Mr. A.K. Joseph is the General Manager of it. The industry has started in year 1974. The industry collects the milk and pasturieses it first. The various processes held in the dairy are discussed below:
1) Pastarisation
2) Powderisation
3) Butter making
4) Ghee making
5) Cheese making
6) Preparation of whole milk and skimmed milk. This process are shortly described already in chapter II "Literature Review"

The industry has an intake of 50,000L of milk per day in summer and 150,000 L of milk per day in winter season. Industry is having about 625 workers working in three shifts. At KIT, there are 4 persons Mr. A.G. Doshi , Kr. B.S. Thakre, Mr. G.B. Lahor and B.H. Patil. Industry is using about 5 to 6 lakh L of water per day. This water is available from open wells (2 no) and partly from municipal corporation. 


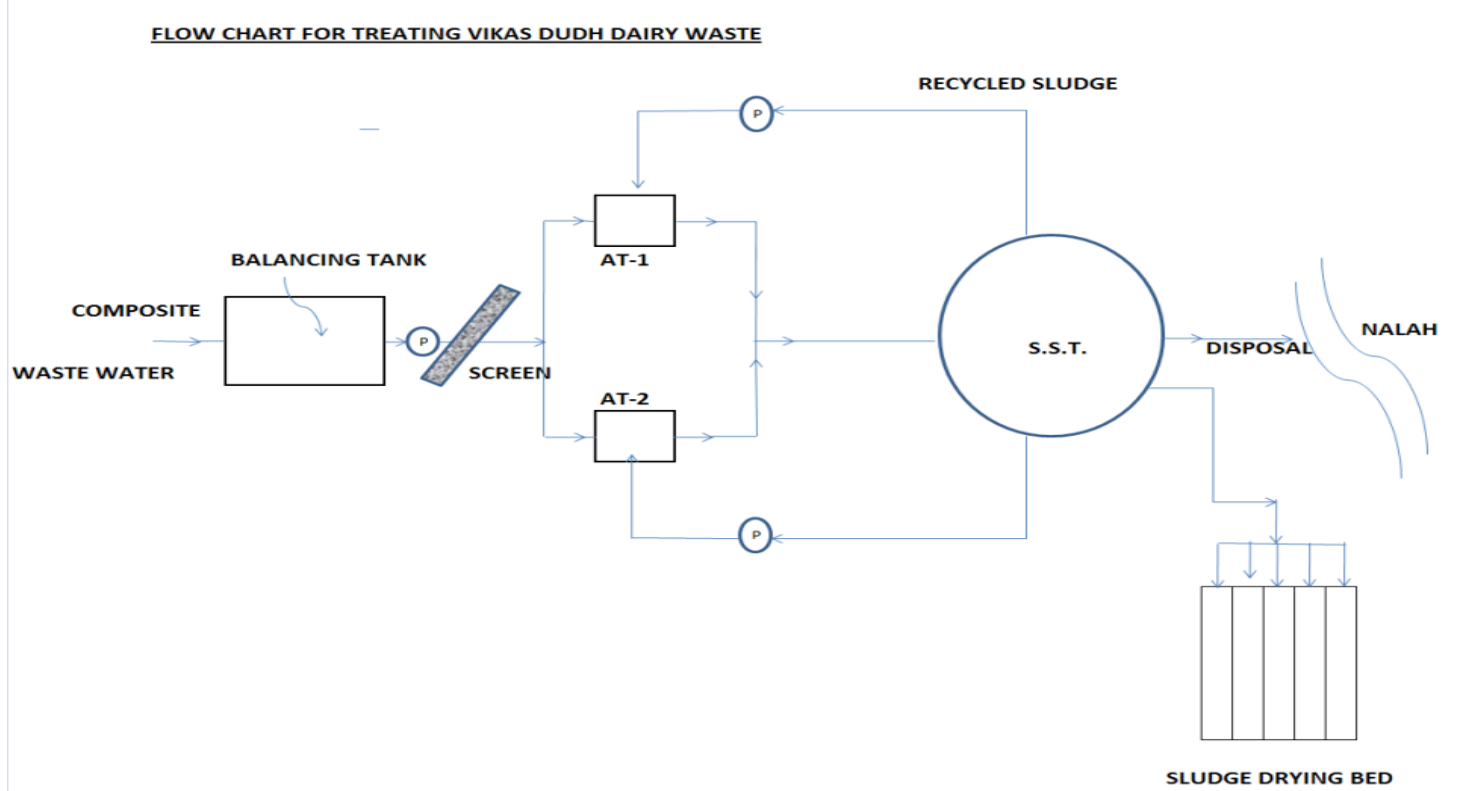

Fig. 1: Flow chart for Treating Vikas Dudh Dairy Waste

\subsection{Housekeeping}

Industry is using 5 lit of water, per lit of milk being processed. This is more than the value of 2 to $4 / 2$ as specified by the LS CODE and NEER' manual, i.e. industry is poor in water management. This may be one of the probable reason zh.7 the B.O.D of composite waste water is lower than what is specified by Indian standard codes. However being a private sector a better water management was expected from the industry In other aspects of environmental management and housekeeping the industry is working well. The spillage is no where observed is observed everywhere, no foul order or characteristics smell is observed within the Premises Security arrangement is tight. The solid waits specially Polythene which is \& specially observed in dairy industries is not found is Tikes Dairy. The effluent treatment plant is working excellent and treated water is reused for irrigation. The treatment plant is having scope for expansion in future. However minor problems are found for which remedies are required. Industry persons had been quite co-operative in showing at the housekeeping. The industry is having a well equipped factory which monitors the E.T.P

\subsection{Effluent Treatment Plant}

The wastewater is collected from different sources and is collecting joining in a balancing tank. From here it is periodically pumped to the other unit of E.T.P It is a single pump of $3.7 \mathrm{kw}$ Capacity Balancing tank is a rectangular tank of size $(7 \times 7 \times 4) \mathrm{m}$. The balancing tank is an important part of the dairy waste water treatment plant. Because dairy effluents fluctuate quality wise and quantity wise too much. As dairy wastewater is highly biodegradable, the balancing tank must is an aerated balancing tank so that anaerobic conditions are avoided. But here the balancing tank is not provided with aerators.
The next unit after balancing tank is screens though dairy waste water ordinary does not contain any thing screen able. Screen are generally provided in treatment plants so that if anything like polythene, paper piece etc. comes by accident' sore litter cones, it may remove them and may gone further units. Next the screen there must be skimming tanks to remove

Oil and grease from waste water. But no skinning tanker is provided in this treatment plants. These will definitely increase the load on subsequent units. It is a significant discrepancy of treatment plant. Next to it the unit is aeration tank. There are two tank of 500000 litter's capacity each in parallel with a size of $12 \times 12 \times 8 \mathrm{~m}$. Each is provided with a fixed surface aerator of 75HP. At a tine only one is operation other tank is empty. Next to that there is a circular settling tank. Aeration tank are having D.O. very near to $2 \mathrm{mg}$ per litter always as we measured. MLSS in secondary tank is in the range of $3000 \mathrm{mg} / \mathrm{lit}$. After secondary settling the effluent is very clear. It is used for irrigation in the prentices of industry and surplus is disposal in to a nearby nala. The sludge of secondary settling tank is partly recycled and partly taken to sludge drying bed is $5 \times 2 \times 1.5 \mathrm{~m}$ in size and is provided with sand filtering media. The dried sludge is till now having no use. Provide size of secondary sedimentation tank $60 \mathrm{~m}$ diameter and provide width $2 \mathrm{~m}$.

\subsection{Methodology Adopted}

The methodology adopted for the E. T. P. monitoring was like this -) We discussed with the industry personals and indentified the peak timings of discharge as loam to $12 \mathrm{pm}$., 3 to $4 \mathrm{pm}$. 6 to $7 \mathrm{pm}$ and 12am (in night) So we collected samples on first 3 peaks and nixed then to get composites samples. The samples were collected from balancing tank with the help of a cane and rope and were spared in a large cane. They were taken to the laboratory and were analyzed 
for various pollution parameters. Simultaneously we measured D.O. content of aeration tank by taking samples and fixing the oxygen at the site itself by chemicals. We collected samples once each time from aeration tanks for the analysis of M.L.S.S. once in a day the heated effluent was collected for analysis of pollution parameters and D.O. also. For that D.O. sample was separately collected in a bottle and was fixed at the site itself $\mathrm{PH}$ was measured in the laboratory. Because it was not feasible to take the $\mathrm{pH}$ meter up to site. Sample collected up evening were stored in a freeze at room temperature were taken to the laboratory for analysis. The important thing is that during our testing the B.O.D. incubator of college laboratory was out of order. For that we took help of the industry and their laboratory they allowed us for B.O.D. testing.

Table 1: Characteristics of composites waste water

\begin{tabular}{|l|l|l|l|}
\hline Sr.no. & Characteristics & Unit & Value \\
\hline 1. & BOD5 @ 20 ${ }^{0} \mathrm{C}$ & $\mathrm{mg} / 1$ & 530 \\
\hline 2. & COD & $\mathrm{mg} / 1$ & 790 \\
\hline 3. & $\mathrm{pH}$ & -- & 6.5 \\
\hline 4. & Total solid & $\mathrm{mg} / 1$ & 2532 \\
\hline 5. & Total dissolved solid & $\mathrm{mg} / 1$ & 1803 \\
\hline 6. & Total suspended solid & $\mathrm{mg} / 1$ & 729 \\
\hline 7. & Total fixed solid & $\mathrm{mg} / 1$ & $63 \mathrm{~g}$ \\
\hline 8. & Total volatile solid & $\mathrm{mg} / 1$ & 1702 \\
\hline 9. & Dissolved fixed solid & $\mathrm{mg} / 1$ & 1562 \\
\hline 10. & Alkalinity & $\mathrm{mg} / 1$ & 213 \\
\hline
\end{tabular}

Table2. Characteristics of treated effluent

\begin{tabular}{|l|l|l|l|}
\hline Sr.no. & Characteristics & Unit & Value \\
\hline 1. & BOD5 @ 20 ${ }^{\circ} \mathrm{C}$ & $\mathrm{mg} / 1$ & 10 \\
\hline 2. & COD & $\mathrm{mg} / 1$ & 260 \\
\hline 3. & $\mathrm{pH}$ & -- & 7.2 \\
\hline 4. & Total solid & $\mathrm{mg} / 1$ & 1103 \\
\hline 5. & Total dissolved solid & $\mathrm{mg} / 1$ & 1036 \\
\hline 6. & Total suspended solid & $\mathrm{mg} / 1$ & 30 \\
\hline 7. & Total fixed solid & $\mathrm{mg} / 1$ & 1030 \\
\hline 8. & Total volatile solid & $\mathrm{mg} / 1$ & 96 \\
\hline 9. & Alkalinity & $\mathrm{mg} / 1$ & 270 \\
\hline
\end{tabular}

\section{MONITORING OF AERATION TANK}

Interpretation: - From the above results. It can be interpretable that:

i. $\quad$ BOD is less than what is given in 1.5 code 8673

ii. $\mathrm{BOD} / \mathrm{COD}$ ratio is $530 / 790=0.67$. So wastes highly biodegradable

iii. $\quad \mathrm{pH}$ is slightly acidic

iv. Alkalinity is good.

v. D.O. available in aerahin tank as good

vi. M.L.S.S.

vii. Treatment leads to every clear effluence. 'It can be disposal safety.
Table 3. Characteristics of composite waste water

\begin{tabular}{|l|l|l|l|}
\hline $\begin{array}{l}\text { Sr.n } \\
\text { o. }\end{array}$ & Characteristics & Unit & Value \\
\hline 1. & BOD $_{5} @ 20^{0} \mathrm{C}$ & $\mathrm{mg} / 1$ & 585 \\
\hline 2. & $\mathrm{COD}$ & $\mathrm{mg} / 1$ & 810 \\
\hline 3. & $\mathrm{pH}$ & -- & 6.7 \\
\hline 4. & Total solid & $\mathrm{mg} / 1$ & 2608 \\
\hline 5. & Total dissolved solid & $\mathrm{mg} / 1$ & 1912 \\
\hline 6. & Total suspended solid & $\mathrm{mg} / 1$ & 696 \\
\hline 7. & Total fixed solid & $\mathrm{mg} / 1$ & 818 \\
\hline 8. & Total volatile solid & $\mathrm{mg} / 1$ & 1790 \\
\hline 9. & Alkalinity & $\mathrm{mg} / 1$ & 228 \\
\hline
\end{tabular}

Table 4 Characteristics of treated effluent

\begin{tabular}{|l|l|l|l|}
\hline Sr.no. & Characteristics & Unit & Value \\
\hline 1. & BOD5 @ 20 ${ }^{\circ} \mathrm{C}$ & $\mathrm{mg} / 1$ & 18 \\
\hline 2. & COD & $\mathrm{mg} / 1$ & 243 \\
\hline 3. & $\mathrm{pH}$ & -- & 7.0 \\
\hline 4. & Total solid & $\mathrm{mg} / 1$ & 1218 \\
\hline 5. & $\begin{array}{l}\text { Total dissolved } \\
\text { solid }\end{array}$ & $\mathrm{mg} / 1$ & 1170 \\
\hline 6. & $\begin{array}{l}\text { Total suspended } \\
\text { solid } \mathrm{mg} / 1\end{array}$ & 48 \\
\hline 7. & Total fixed solid & $\mathrm{mg} / 1$ & 1120 \\
\hline 8. & Total volatile solid & $\mathrm{mg} / 1$ & 98 \\
\hline 9. & Alkalinity & $\mathrm{mg} / 1$ & 250 \\
\hline
\end{tabular}

\section{CHARACTERISTICS OF AERATION TANK}

$\begin{array}{ll}\text { M. L. S. S. } & 3608 \mathrm{mg} / \mathrm{I} \\ \text { D.O. } & 2.0 \mathrm{mg} / \mathrm{I}\end{array}$

Interpretation: - From the above results. It can be interpretable that:

i. BOD is less than what is given in LS. code 8673

ii. $\mathrm{BOD} / \mathrm{COD}$ ratio is $585 / 810=0.72$. So waste highly biodegradable

iii. $\mathrm{pH}$ is slightly acidic

iv. Alkalinity is good.

v. D.O. available in aeration tank as good.

vi. M. L. S. S.

Treatment leads to every clear effluent. It can be disposal safety. After designing of all treatment units .following comparison can be made.

Table 5 Comparison Table of Design verification of treatment Unit

\begin{tabular}{|l|l|l|l|}
\hline $\begin{array}{l}\text { Sr. } \\
\text { No. }\end{array}$ & Type of Unit & $\begin{array}{l}\text { Design size } \\
\text { of Unit }(\mathrm{m})\end{array}$ & $\begin{array}{l}\text { Existing size } \\
\text { of unit }(\mathrm{m})\end{array}$ \\
\hline 1. & Screens & $5 \times 1 \times 1.4$ & $6 \times 1 \times 1.4 \mathrm{~m}$ \\
\hline 2. & Skimming tank & $5 \times 5 \times 3$ & $7 \times 7 \times 4 \mathrm{~m}$ \\
\hline 3. & Aeration tank & $21 \times 15 \times 8$ & $\begin{array}{l}12 \times 12 \times 8 \\
\mathrm{~m}\end{array}$ \\
\hline
\end{tabular}




\begin{tabular}{|c|c|c|c|}
\hline 4. & $\begin{array}{l}\text { Secondary } \\
\text { sedimentation tank }\end{array}$ & $\begin{array}{l}63 \mathrm{~m} \text { dia } x \\
2 \mathrm{~m} \text { width }\end{array}$ & $\begin{array}{l}60 \mathrm{~m} \text { dia } x \\
2 \mathrm{~m} \text { width }\end{array}$ \\
\hline 5. & Sludge drying bed & $8 \times 10 \times 1.2$ & $5 \times 2 \times 1.5 \mathrm{~m}$ \\
\hline
\end{tabular}

Note: The provided sizes of various units of treatment plants are within required range.

\section{CONCLUSIONS}

The following conclusion could be drawn from this work.

1. Dairy industry is a very important and lastly growing food processing industry of world. (1)

2. Dairy waste water is an a rear already explored a lot. Sufficient literature is easily available. (I)

3. Dairy waste water is simply diluted milk (1)

4. Dairy waste water is highly biodegradable and aerobic biological treatment is most feasible. (3)

5. VIKAS DAIRY - is good in house keeping, but they require more quantity of water than average.

6. The composite waste water is poor in BOD (Very near to 50014/1) which can be directly disposed on land, without treatment. The value of BOD is much less than that is reported by IS code.

7. Industry is having a well equipped laboratory for monitoring the E.T.P.

8. House Keeping:-House keeping refers to the cleanliness and maintenance aspects of the industry. The Vikas dairy Jalgaon ranks very high in terms of housekeeping. The dairy has obtained ISO 90012008 certification that includes housekeeping aspect also. The dairy has maintained a very good dairy. Greenery all around using its own wastewater. This greenery not only gives a good look to the industry but also prevents the dust which is a requirement of dairy industry. In Vikas dairy nowhere foul smell comes. All floors are washed after every shift. Pipe lines and containers are cleaned regularly. The milk cans are washed by automatic machines using hot stream and caustic. Nowhere in industry can fly or insects be observed. They controlled by sprinkling insecticides in surroundings. The solid waste is collected and removed in an organized way. The flyinsects are controlled by UV lamps also. All workers used specially designed caps to control fall of hair. They wear uniforms of their cadre and keep it clean. Everywhere hard washing facility along with $\mathrm{Cl}_{2}$ water is available. Workers clean their hands before entering into specified units. In overall, the housekeeping of Vikas dairy is appreciable.

\section{SCOPE OF FUTURE WORK}

Every research work is always a foundation for future research work. The present work leads to the following lines for future work.

1. Quantitative analysis of different channel of waste water is a must for working out a rational design of balancing tank. (3)

2. The balancing tank requires a bubble action system. For that, optimum capacity system must be worked out.

3. The treatment plant requires skimming tank. For that pilot plant studies must be carried out for adopting a suitable size of plant or aerated skimming tank.

4. The secondary setting tanks leads to slightly higher concentration of suspended solids. for that the recirculation ratio needs to be adjusted.

5. The dried sludge must be analyzed for its H.P.K. value (fertility value) and humic acid content and $\mathrm{PH}$ variations with tine, so that it may be used as a compost.

6. The alternative treatment methods must be analyzed for the waste water. Because, today, it is the time for anaerobic treatment methods. So, pilot plant studies with other method than activated sludge must be carried out.

7. The process of the industry must be very carefully maintained so that the loop holes may be checked, the industry is using under stability higher value of water, per unit of milk processed. This way/the water consumption might be reduced. However, it may defect the BOD of composite waste water. If it is so, the entire plant may require redesign.

\section{REFERENCES}

[1] .Banes D. Forster, Hrudey S.E. Survey Industrial Waste Water Treatment, Vol. 1 : Food \& Allied Industries.

[2]. Course manual Industrial waste treatment proposed by NEERI and CPHEEO, 1975.

[3]. I.E. 2490-1982 Indian Standards for Industrial and Sewage Effluent Discharge.

[4]. LS. 8682-1983 Indian Standards for Dairy Wastewater. [5]. .Nemerow Nelson J. Industrial Water Pollutions Origins Characteristics and Treatments Addison Wesley Publishing Company.

[6]. Standard methods for the examination of water and wastewater $17^{\text {th }}$ Edition APHA New York, 1984. 